\title{
Estimating ashe juniper leaf area from tree and stem characteristics
}

\author{
R.A. HICKS AND W.A. DUGAS
}

Authors are research associate, and professor and resident director of Blackland Research Center, Texas A\&M University System-Texas Agricultural Experiment Station, Temple, Tex. 76502.

Abstract

Ashe juniper (Juniperus ashei Buchh.) is increasing in density and areal coverage on the Edwards Plateau of Texas. This is causing changes in community leaf area that could impact the ecosystem water balance through increased transpiration and interception of precipitation. Our objective was to estimate leaf area of selected trees and shoots in a range of size and age classes using nondestructive methods. We harvested all leaf material from 9 trees ranging in height from 0.8 to $4.8 \mathrm{~m}$ and recorded tree height and canopy diameter. We divided each tree into 6 sections based on 3 horizontal strata and 2 vertical hemispheres. Projected leaf area of subsamples, collected from each section, was multiplied by $\pi$ to give full cylinder leaf area which was used to calculate specific leaf area $\left(\mathrm{cm}^{2} \mathrm{~g}^{-1}\right)$. Dried leaf biomass for each stratum, hemisphere, and tree was multiplied by the specific leaf area to determine the leaf area. We harvested leaf biomass from shoots and measured in situ stem diameters, dried the leaf biomass, and multiplied it by the specific leaf area to determine shoot leaf area. There was no significant effect of stratum or hemisphere on specific leaf area or of hemisphere on leaf area. The middle stratum had a significantly greater percentage of total leaf area $(52 \%)$. Total tree leaf area was best predicted $\left(r^{2}=0.97\right)$ by canopy area. Shoot leaf area was best predicted $\left(r^{2}=0.93\right)$ by stem area. Canopy and stem area measurements are rapid, nondestructive means of accurately estimating Ashe juniper tree and shoot leaf area, respectively.

Key Words: Juniperus ashei, specific leaf area, canopy area, stem area, tree height

Density and areal coverage of Ashe juniper (Juniperus ashei Buchh.) have increased on Texas rangelands (Smeins et al. 1994). Removal of this species can increase the fraction of precipitation available for runoff and soil moisture recharge (Dugas et al.1998). Because Ashe juniper leaf area affects transpiration (Dugas et al. 1998, Owens 1996) and precipitation interception (Thurow and Carlson 1994), estimates of its leaf area are useful for understanding the impacts on ecosystem water balance.

\footnotetext{
This work was supported in part by USDA-NRCS Grant No. 68-7442-0-91 Manuscript accepted 11 Jan. 1998
}

\section{Resumen}

La densidad y área cobierta por Ashe juniper (Juniperus ashei Buchh.) está aumentando en la región de Edwards Plateau en Texas. Esto está produciendo cambios de área foliar en la comunidad vegetal, lo cual podria afectar el balance hídrico del ecosistema cambiando los procesos de transpiración e intercepción de Huvia. Nuestro objetivo fuc estimar el área foliar de árboles y de ramas utilizando muestreo no destructivo. Para tal efecto, los arboles fueron clasificados de acuerdo al tamaño y edad. Colectamos todo el material foliar de 9 árboles entre 0.8 y $4.8 \mathrm{~m}$ de altura y registramos alturas y diámetros de copa de los árboles. Cada copa de árbol fué separada en 6 secciones que resultaron de 3 estratos horizontales y 2 hemisferios verticales. El área foliar proyectada de las submuestras, colectadas de cada sección, fué multiplicada por II para obtener el área foliar cilíndrica, que fué posteriormente usada para calcular el área foliar específica $\left(\mathrm{cm}^{2} \mathrm{~g}^{-1}\right)$. La materia seca de cada estrato, hemisferio, y árbol fué multiplicada por el área foliar específica para determinar el área foliar respectiva. Sacamos todo el material foliar de las ramas y registramos el diámetro del tronco de la rama in situ. El material vegetal fué secado y su masa fué multiplicada por el área foliar específica para determinar el área foliar de la rama. No hubo efecto significativo de estrato o de hemisferio en el área foliar especifica, ni de hemisferio en el área foliar. El estrato intermedio presentó un porcentaje de área foliar $(52 \%)$ significativamente superior con respecto a los otros dos estratos. El área foliar total para el árbol fué mejor estimada por el área de la copa proyectada en el suelo. El área foliar total para las ramas fué mejor estimada por el área del tronco de la rama. Determinaciones del área de la copa y del tronco de las ramas no son destructivas y pueden efectuarse rapidamente para la obtención del área foliar del árbol y de las ramas de Ashe juniper.

Direct measurement of whole tree leaf area is difficult and, therefore, various methods of estimating it have been developed (Miller et al. 1987). Smith et al. (1991), Gower and Norman (1991), and DeBlonde et al. (1994) showed that allometric methods yielded better estimates of conifer leaf area than light interception or plant canopy analyzer measurements. 
Commonly-uscd allomctric measurcments relate whole-trec leaf area to tree or canopy height, trunk diameter or sapwood area, and specific leaf area and leaf biomass (White 1983, Miller et al. 1987, Vertessy et al. 1995). Trunk diameter and sapwood area are not easily obtained for Ashe juniper because it often has numerous main shoots that emerge from a short, furrowed trunk, and it often has a broad globular or open, irregular crown (Correll and Johnston 1970). Mason and Hutchings (1967) determined that canopy diameter measurements produced accurate estimates of foliage yield in Juniperus osteosperma.

Leaf area has been shown to differ from one part of a canopy to another due to microenvironmental factors (Hager and Sterba 1984, Borghetti et al. 1986, Chapman and Gower 1991, McCrady and Jokela 1996). This can affect the accuracy of whole-tree leaf area estimates based on specific leaf area and biomass.

No studies have been reported that provide a method for estimating whole tree Ashe juniper leaf area. The objective of this study was to assess the use of allometric measurements to estimate leaf area for trees and shoots in a range of size and age classes. We quantified the relationships between 1) specific leaf area and canopy position, 2) leaf area and canopy position, 3) tree leaf area and tree height, canopy diameter and canopy area, and 4) shoot leaf area and stem diameter and stem area. Our results were used to interpret energy balance studies (Dugas et al. 1998) and hydrologic modeling efforts (Muttiah et al. 1996) at the same site.

\section{Materials and Methods}

\section{Study Site}

This study was conducted about $70 \mathrm{~km}$ west of San Antonio, Tex., U.S.A., in the northeast corner of Uvalde County $\left(29^{\circ} 35^{\prime} \mathrm{N}\right.$ $\left.99^{\circ} 27^{\prime} \mathrm{W}\right)$. The site was at an elevation of about $450 \mathrm{~m}$ on a south facing slope of about $10 \%$. Soils belong to the Rockland-RealEckrant association (Lithic Haplustolls and Typic Calciustolls) (USDA- SCS and TAES 1970). They are shallow to very shallow; gravelly, loamy and clayey with 35 to $85 \%$ coarse fragments; and underlain at 0.1 to $0.5 \mathrm{~m}$ by indurated, fractured, limestone bedrock.

Average annual precipitation is about $750 \mathrm{~mm}$ with maxima in May and September. The average minimum January temperature is $2^{\circ} \mathrm{C}$ and the average maximum August temperature is $35^{\circ} \mathrm{C}$. The freeze-free period, about 230 days, begins about 25 March (NOAA 1978 and 1985).

\section{Vegetation}

About $90 \%$ of the approximately 1,000 trees $\mathrm{ha}^{-1}$ at the site were Ashe juniper (Dugas et al. 1998) that ranged from less than 1 to about $5 \mathrm{~m}$ in height (average $=2.7 \mathrm{~m}$ ) and had multiple shoots rising from an irregular, basal crown. Based on visual observations, about half of the Ashe juniper trees at the site were individual trees. Although about half of the total Ashe juniper trees at the site had medium density foliage, only about half of these were individual trees. Historical land management practices indicate the sample trees were less than 40 years old.

\section{Procedures}

Nine trees were harvested from February through September 1995 (Table 1), ranging from 0.8 to $4.8 \mathrm{~m}$ in height. This sample, which spanned the range of size and age classes of trees at the site, was small due to the time and labor constraints of removing and processing all the leaf material from each tree. Trees were selected that had medium density foliage (Mason and Hutchings 1967) and no neighbors within $1.5 \mathrm{~m}$ that could affect the canopy. This was done to limit the between-tree variability in leaf and canopy area and to facilitate our ability to assess the relationship of the allometric measurements to leaf area. Tree height (which was equal to canopy height) and canopy diameter were recorded for each tree. Tree height was measured from the soil surface to the tallest point of the tree. Canopy diameter was estimated as the average of 2 perpendicular directions, with one being the widest part of the tree. Canopy area was calculated assuming the canopy was circular. This assumption was valid since the average difference between the 2 diameters per tree was only $11 \%$ (Table 1) and calculating the canopy area using an equation for an ellipse changed the canopy area by less than $2 \%$ for each tree.

Many plants exhibit differences in specific leaf area for shade vs. sun leaves, which can cause differences in leaf area between canopy positions (Hager and Sterba 1984, Borghetti et al. 1986, Chapman and Gower 1991, McCrady and Jokela 1996). Therefore, each tree was divided into 6 sections based on 3 horizontal strata and 2 vertical hemispheres. The 3 strata were top, middle, and bottom, with the height of each stratum being $1 / 3$ of total tree height. Hemispheres were defined by a northeast to southwest vertical plane through the canopy center (Owens 1996).

Juniper "leaves" were defined to be the groups of scale leaves arranged in whorls around a twig in "needle-like clumps" as described by Miller et al. (1987) and Cregg (1992). One fresh subsample (10 to $40 \mathrm{~g}$ dry mass) was collected from each section

Table 1. Ashe juniper trees harvested in 1995 for specific leaf area, leaf area, and canopy leaf area index. Canopy leaf area index is the leaf area ( $\mathrm{m}^{2}$ ) over the area of soil surface $\left(\mathrm{m}^{2}\right)$ covered by the canopy.

\begin{tabular}{|c|c|c|c|c|c|c|c|}
\hline $\begin{array}{l}\text { Tree } \\
\text { number }\end{array}$ & $\begin{array}{c}\text { Harvest } \\
\text { Date }\end{array}$ & $\begin{array}{c}\text { Tree } \\
\text { Height }\end{array}$ & $\begin{array}{c}\text { Canopy } \\
\text { Diameter } 1\end{array}$ & $\begin{array}{c}\text { Canopy } \\
\text { Diameter } 2\end{array}$ & $\begin{array}{l}\text { Mean Specific } \\
\text { Leaf Area/std }\end{array}$ & $\begin{array}{c}\text { Total } \\
\text { Leaf Area }\end{array}$ & $\begin{array}{l}\text { Canopy Leaf } \\
\text { Area Index }\end{array}$ \\
\hline & & $(\mathrm{m})$ & $(\mathrm{m})$ & (m) & $\left(\mathrm{cm}^{2} \mathrm{~g}^{-1}\right)$ & $\left(\mathrm{m}^{2}\right)$ & $\left(m^{2} m^{-2}\right)$ \\
\hline 1 & 3 Feb. & 1.15 & 1.05 & 1.05 & $57 / 2.4$ & 4.9 & 5.6 \\
\hline 2 & 3 Feb. & 0.80 & 0.65 & 0.50 & $62 / 12.5$ & 0.6 & 2.5 \\
\hline 3 & 3 Feb. & 1.25 & 1.50 & 1.25 & $59 / 2.2$ & 4.9 & 3.3 \\
\hline 4 & $16 \mathrm{Mar}$. & 4.35 & 4.40 & 4.20 & $51 / 2.9$ & 159.8 & 11.0 \\
\hline 5 & 6 Apr. & 3.05 & 3.70 & 3.60 & $52 / 0.7$ & 96.0 & 9.2 \\
\hline 6 & 2 May & 4.80 & 6.10 & 4.70 & $49 / 2.1$ & 290.0 & 12.7 \\
\hline 7 & $12 \mathrm{Jul}$. & 2.50 & 2.80 & 2.50 & $60 / 11.0$ & 48.7 & 8.8 \\
\hline 8 & 2 Aug. & 3.15 & 3.90 & 3.60 & $52 / 1.4$ & 89.0 & 8.1 \\
\hline 9 & 6 Sep. & 2.15 & 2.85 & 2.60 & $44 / 3.5$ & 44.1 & 7.5 \\
\hline
\end{tabular}


per tree for calculating specific leaf area $\left(\mathrm{cm}^{2} \mathrm{~g}^{-1}\right)$. We did not differentiate current year foliage from prior year foliage because there was no distinct generation or senescence period (Owens and Schreiber 1992). Each subsample, therefore, included multi-aged leaf material suggesting that season of harvest should have less effect on specific leaf area.

Specific leaf area was determined by dissecting the clumps on each twig to individual, needle-like units to reduce error of projected leaf area. Projected leaf area of the fresh subsamples was measured with an area meter (LiCor LI3000, Lincoln, Nebr.) and multiplied by $\pi$ to obtain the cylindrical area. We have termed this "full cylinder leaf area". This method is reported to underestimate leaf area by 3 to $10 \%$, but corrects for the cylindrical nature of the juniper leaf (Miller et al. 1987, Cregg 1992) and accounts for the nonrandom distribution and orientation of conifer leaves (Sprugel 1989, Gower and Norman 1991). The subsamples were dried and weighed, and specific leaf area was calculated.

Leaf area in each tree section was determined by removing all stems and attached leaves, drying at $60^{\circ} \mathrm{C}$ for about 7 days, and separating stems from leaves. Leaf biomass was then dried for 5 days, weighed, and multiplied by the average specific leaf area, which was constant across trees (Table 1) and sections (Table 2) to determine section leaf area. Leaf areas from sections were summed to calculate leaf area for the stratum, hemisphere and tree.

The relationship between stem area and shoot leaf area was estimated by selecting shoots $(n=97)$ from both hemispheres of trees with medium density foliage. Two perpendicular measurements of in situ stem diameter, including the bark, were made with calipers at a point where the stem was not deformed by branching. The distance from this point to the next distal branch ranged from 10 to $150 \mathrm{~mm}$. Stem area was calculated using the average stem diameter assuming the stem was circular. All leaf biomass and twigs distal to the measurement point were removed from the shoot, dried, separated, and re-dried. To determine shoot leaf area, leaf biomass was weighed and multiplied by the average specific leaf area previously estimated for trees.

\section{Statistical Analyses}

Analysis of variance using the Least Significant Difference method was used to compare the mean specific leaf area across scetions, strata, hemispheres, and trees. For a given trec or section of tree, leaf area was a function of tree size. Therefore, the percentage of total tree leaf area in each stratum and hemisphere was used in the analysis of variance with the Least Significant Difference method to compare leaf area across strata and hemispheres. Regression equations for the relationships between leaf area and plant measurements were developed using linear least squares regression. The Shapiro- Wilk statistic and scatterplots of residuals were used to test normality and random distribution of residuals, respectively (SAS 1988).

\section{Results and Discussion}

\section{Specific Leaf Area}

Specific leaf area was similar $(\mathrm{P}>0.05)$ for all sections of the 9 trees that were sampled (Table 2). Specific leaf area was also similar $(P>0.05)$ when compared across strata or hemispheres (results not shown). Spatially-uniform specific leaf area within
Table 2. Average specific leaf area (SLA) for different sections of 9 Ashe juniper trees. Sample standard deviation is shown in parentheses.

\begin{tabular}{ll}
\hline \hline Section & SLA \\
\hline & $\left(\mathrm{cm}^{2} \mathrm{~g}^{-1}\right)$ \\
Northwest-Top & $54.9(4.7)$ \\
Northwest-Middle & $52.7(8.5)$ \\
Northwest-Bottom & $53.5(4.9)$ \\
Southeast-Top & $56.1(11.8)$ \\
Southeast-Middle & $51.9(4.1)$ \\
Southeast-Bottom & $56.3(10.6)$ \\
Average & $54.3(7.9)$ \\
\hline
\end{tabular}

the canopy and across trees is unusual (Hager and Sterba 1984, Borghetti et al. 1986, Chapman and Gower 1991, Cregg 1992, Vertessy et al. 1995, McCrady and Jokela 1996). This result likely occurred in this study due to the inclusion of multi-aged leaf material.

Our average specific leaf area (Table 2 ) is similar to the specific leaf area of $J$. occidentalis $\left(63 \mathrm{~cm}^{2} \mathrm{~g}^{-1}\right)$ (Miller et al. 1987) and $J$. pinchotii $\left(56 \mathrm{~cm}^{2} \mathrm{~g}^{-1}\right)$ (Ansley, personal communication), but is lower than that reported for J. scopulorum and J. virginiana (115 $\mathrm{cm}^{2} \mathrm{~g}^{-1}$ ) (Cregg 1992). Our juniper leaves included the structural tissues of the twig, which decreased the specific leaf area. The potential for methodological differences between studies exists because there is no clearly defined physical point at which the leaf begins or ends.

\section{Canopy Section Leaf Area}

Leaf areas on the southeast and northwest sides of the trees were similar $(P=0.67)$ with $51 \%$ in the southeast hemisphere and $49 \%$ in the northwest hemisphere (Fig. 1). This equality of leaf area in each hemisphere for trees from a range of size classes differs slightly from the results of Owens (1996) who estimated for 3 mature Ashe juniper trees, the southeast side had $7 \%$ more leaf area than the northwest side.

Leaf area was almost always greatest in the middle stratum and increased nonlinearly as a function of tree height (Fig. 2). When compared as a percentage of tree leaf area, the middle stratum leaf area was significantly $(P=0.0001)$ greater $(52 \%, S D=7)$ than that in the bottom and top strata $(19 \%, \mathrm{SD}=13$ and $29 \%$, SD $=12$, respectively), which were not significantly different. Owens (1996) also found that $54 \%$ of total Ashe juniper leaf area was in the middle stratum and there was no significant difference in the bottom and top strata. McCrady and Jokela (1996) found more than $60 \%$ of total leaf area in the middle stratum of the canopy of loblolly pine trees.

The greater proportion of leaf area in the middle straturn resulted from the broadly globular broadly globular growth form. Although we did not consider tree shape when selecting the trees, the longest diameter of most of our study trees occurred within the middle canopy stratum.

\section{Total Tree Leaf Area}

Total tree leaf area was related linearly to canopy area $\left(\mathrm{r}^{2}=0.97\right)$ (Fig. 3). Our results (Fig. 3) are supported by those of Johnson (unpublished data). Total tree leaf area was nonlinearly related to tree height (Table 1 and Fig. 2) and canopy diameter (Table 1). 


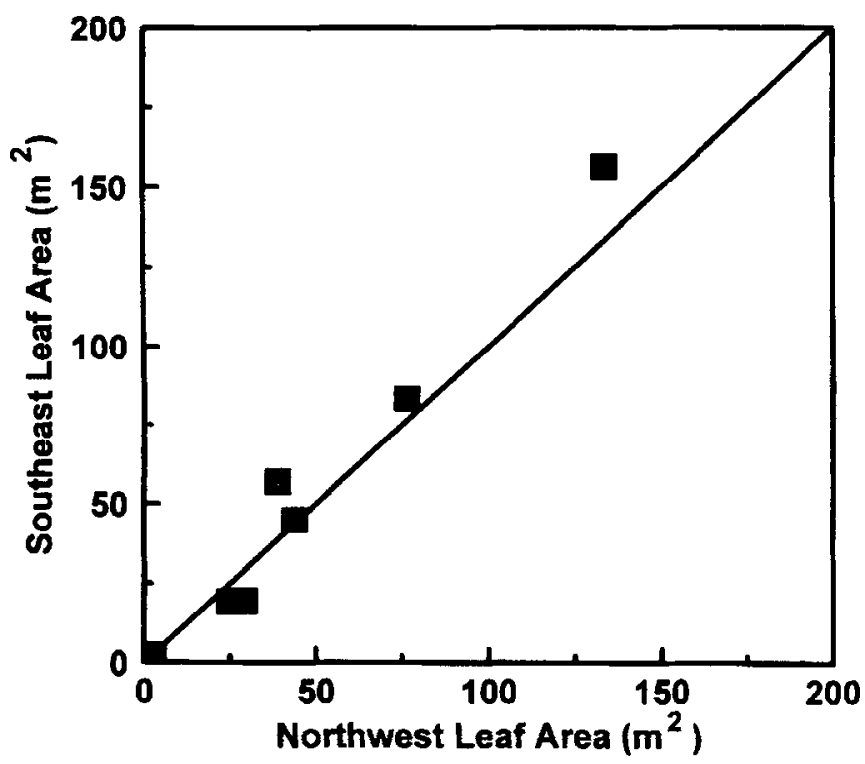

Fig. 1. Leaf area (full cylinder) in the northwest and southeast hemispheres of nine Ashe juniper trees. The 1:1 line is shown.

Therefore, for Ashe juniper trees similar to those we selected, total tree leaf area can be easily and accurately estimated from canopy area that could, for example, be measured from aerial photographs.

Canopy leaf area index was related linearly to tree height (Table 1). Owens (1996) reported canopy leaf area index ranging from 12 to 17 for 2.5 to $3.5 \mathrm{~m}$ tall trees.

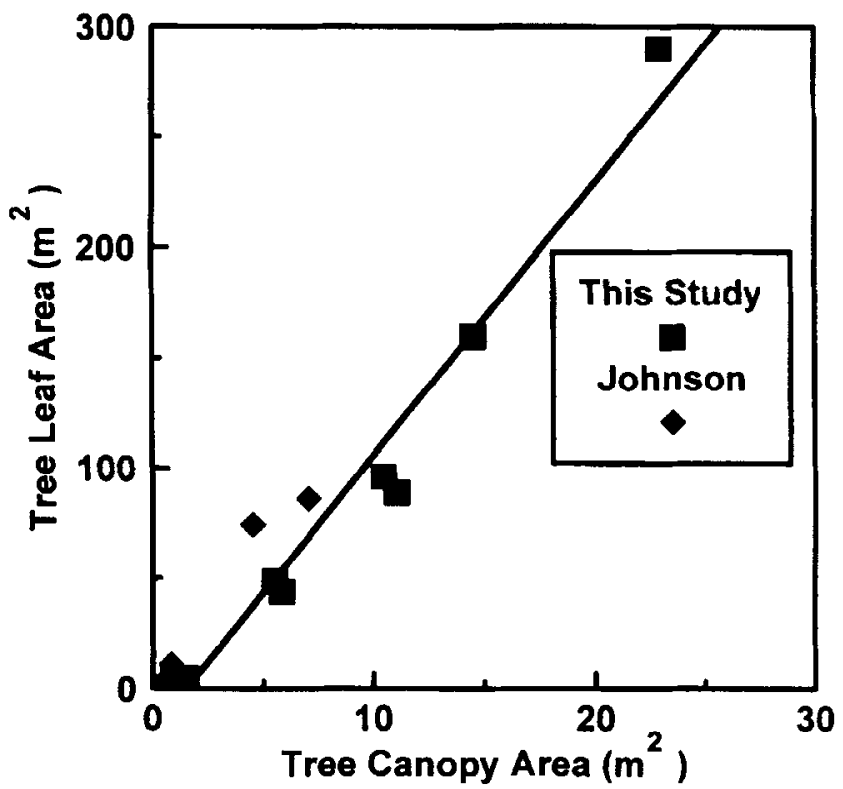

Fig. 3. Total leaf area (full cylinder) for nine Aste juniper trees as a function of canopy area. The linear regression equation $\left(r^{2}=0.97\right)$ is tree leaf area $\left(\mathrm{m}^{2}\right)=-18.5\left(\mathrm{~m}^{2}\right)+12.4\left(\mathrm{~m}^{2} \mathrm{~m}^{-2}\right)$ * canopy area $\left(\mathrm{m}^{2}\right)$. The intercept was not significantly different from $0.0(P=$ 0.08). Data from Johnson (unpublished) are also shown.

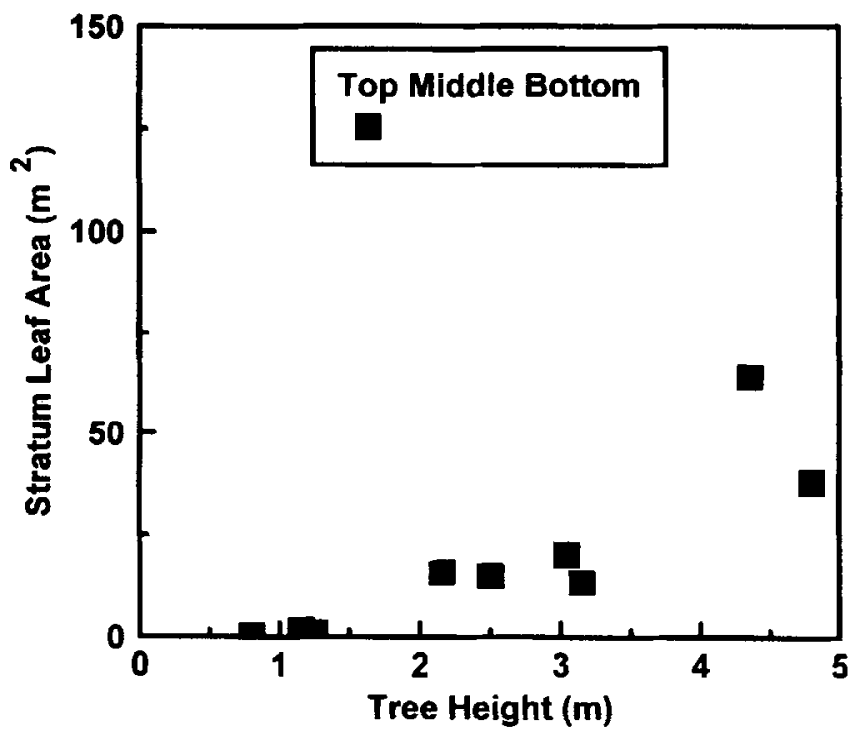

Fig. 2. Leaf area (full cylinder) in the top, middle, and bottom strata of nine Ashe juniper trees as a function of tree height.

\section{Shoot Leaf Area}

Shoot leaf area was related linearly to stem area $\left(r^{2}=0.93\right)$ (Fig. 4). Several studies have found that sapwood area is a good predictor of leaf area $\left(r^{2}=0.70\right.$ to 0.95$)$ (Borghetti et al. 1986, Coyea and Margolis 1992, Callaway et al. 1994), while others have used stem diameter or circumference $\left(\mathrm{I}^{2}=0.78\right.$ to 0.99 ) (Gower et al.1987, Miller et al. 1987). The linear relationship of shoot leaf area to stem area in this study allows easy and accurate estimation of total shoot leaf area from nondestructive, stem diameter measurements.

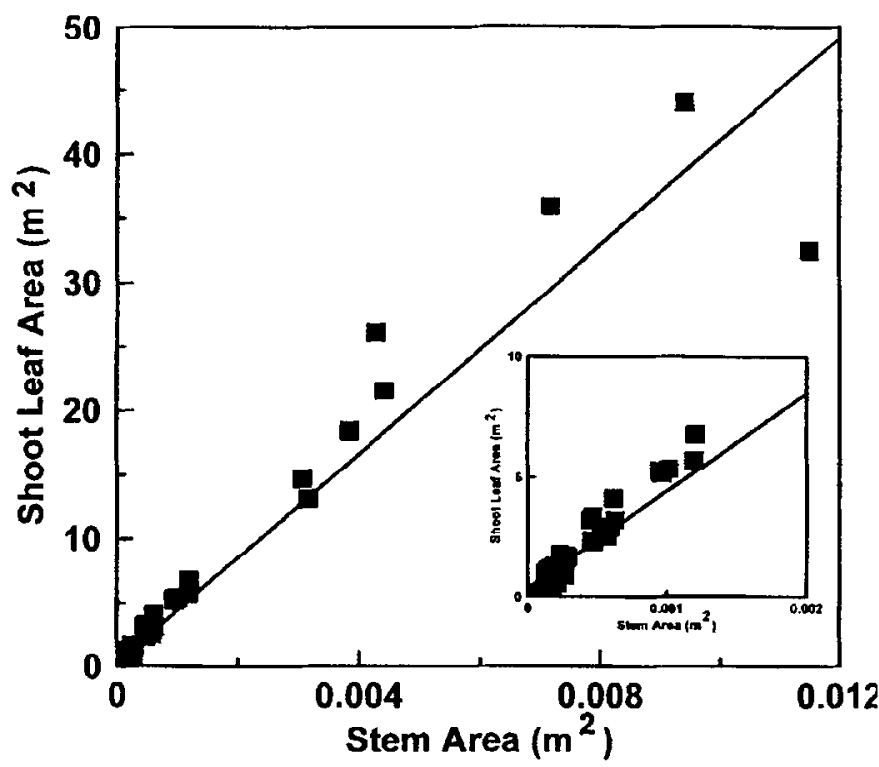

Fig. 4. Shoot leaf area (full cylinder) for 97 Ashe juniper stems as a function of stem area. The linear regression equation $\left(r^{2}=0.93\right)$ is shoot leaf area $\left(\mathrm{m}^{2}\right)=0.338\left(\mathrm{~m}^{2}\right)+4073\left(\mathrm{~m}^{2} \mathrm{~m}^{-2}\right)$ * stem area $\left(\mathrm{m}^{2}\right)$. Inset shows detail at low values. 


\section{Conclusions}

Total tree leaf area was best estimated by canopy area and shoot leaf area was best estimated by stem area. Accurate estimates of total tree leaf area and shoot leaf area can be made from rapid, nondestructive measurements of canopy and stem diameter, respectively.

This study demonstrated that measurements available from remote sensing techniques can produce accurate estimates of Ashe juniper tree leaf area. We believe, based on similarity of tree shape, that canopy area and stem area will produce accurate leaf area estimates for other species of Juniperus (e.g. J. virginiana, J. osteosperma, and $J$. pinchotii), but may not be appropriate for very mature trees whose canopy shape may change considerably or for trees whose canopy is significantly affected by nearby vegetation.

Ashe juniper trees also exhibit sparse, medium and dense foliage canopies similar to Utah juniper whose biomass yield was shown to vary two fold by Mason and Hutchings (1967). Therefore, further studies to validate these relationships for groups of contiguous trees and for a range of foliage densities would be useful. Further development of the canopy area to leaf area relationship will assist remote sensing and modeling efforts.

\section{Literature Cited}

Borghetti, M., G. G. Vendramin, and R. Giannini. 1986. Specific leaf area and leaf area index distribution in a young Douglas-fir plantation. Can. J. Forest Res. 16:1283-1288.

Callaway, R. M., E. H. Delucia, and W. H. Schlesinger. 1994. Biomass allocation of montanc and descrt ponderosa pine: an analog for response to climate change. Ecol. 75:1474-1481.

Chapman, J. W. and S. T. Gower. 1991. Aboveground production and canopy dynamics in sugar maple and red oak trees in southwestern Wisconsin. Can. J, Forest Res. 21:1533-1543.

Correll, D. S. and M. C. Johnston. 1970. Manual of the Vascular Plants of Texas. Pub. Tex. Res. Foundation, Renner, Tex.

Coyea, M. R. and H. A. Margolis. 1992. Factors affecting the relationship between sapwood area and leaf area of balsam fir. Can. J. Forest Res. 22:1684-1693.

Cregg, B. M. 1992. Leaf area estimation of mature foliage of Juniperus. Forest Sci. 38:61-67.

DeBlonde, G., M. Penner, and A. Royer. 1994. Measuring leaf area index with the Li-Cor LAI- 2000 in pine stands. Ecol. 75:1507-1511.

Dugas, W. A., R. A. Hicks, and P. Wright. 1998. Effect of removal of Juniperus ashei on evapotranspiration and runoff in the Seco Creek watershed. Water Resources Res. 34:1499-1506.

Gower, S. T. and J. M. Norman. 1991. Rapid estimation of leaf area index in conifer and broad-leaf plantations. Ecol. 72:1896-1900.

Gower, S. T., C. C. Grier, D. J. Vogt and K. A. Vogt. 1987.Allometric relations of deciduous (Larix occidentalis) and evergreen conifers (Pinus contorta and Pseudotsuga menziesii) of the Cascade Mountains of central Washington. Can. J. Forest Res. 17:630-634.

Hager, H. and H. Sterba. 1984. Specific leaf area and needleweight of Norway spruce (Picea abies) in stands of different densities. Can. J. Forest Res. 15:389-392.

Mason, L. R. and S. S. Hutchings. 1967. Estimating foliage yields on Utah juniper from measurements of crown diameter. J. Range Manage. 20:161-166.

McCrady, R. L. and E. J. Jokela. 1996. Growth phenology and crown structure of selected loblolly pine families at two spacings. Forest Sci. $42: 46-57$
Miller, R. F., L. E. Eddleman and R. F. Angell. 1987. Relationship of western juniper stem conducting tissue and basal circumference to leaf area and biomass. Great Basin Natur. 47:349-354.

Muttiah, R. S., W. A. Dugas, and R. A. Hicks. 1996. Calibration and validation of the SWAT Model for Seco Creek watershed. In: Seco Creek Water Quality Demonstration Project, 1996 Ann. Proj. Rep.

NOAA. 1978. Climatography of the United States, No. 20. Nat. Climatic Data Center, Nat. Oceanographic and Atmospheric Admin. Asheville, N.C.

NOAA. 1985. Climatography of the United States, No. 20. Climatic summaries for selected sites, 1951-1980, Texas. Nat. Climatic Data Center, Nat. Oceanic and Atmospheric Admin. Asheville, N.C.

Owens, M. K. 1996. The role of leaf and canopy-level gas exchange in the replacement of Quercus virginiana (Fagaceae) byJuniperus ashei (Cupressaceae) in semiarid savannas. Amer. J. Bot. 83:617-623.

Owens, M. K. and M. C. Schreiber. 1992. Seasonal gas exchange characteristics of two evergreen trees in a semiarid environment. Photosynthetica 26(3):389-398.

SAS. 1988. SAS/STAT User's Guide-Release 6.03 edition. and SAS Procedures Guide-Release 6.03 edition. SAS Inst. Cary, N.C.

Smeins, F. E., M. K. Owens, and S. D. Fuhlendorf. 1994. Biology and ecology of Ashe (Blueberry) juniper. P 9-24. Tex. A\&M Univ. Res. Sta. at Sonora, Juniper Symposium 1994. Tech. Rep. 94-2.

Smith, F. W., D. A. Sampson, and J. N. Long. 1991. Comparison of leaf area index estimates from tree allometrics and measured light interception. Forest Sci. 37:1682-1688.

Sprugel, D. G. 1989. The relationship of evergreenness, crown architecture and leaf size. Amer. Natur. 133:465- 479.

Thurow, T. L. and D. H. Carlson. 1994. Juniper effects on rangeland watersheds. P $31-43$. Tex. A\&M Univ. Res. Sta. at Sonora, Juniper Symposium 1994. Tech. Rep. 94- 2.

USDA- SCS and TAES. 1970. Soil Survey of Uvalde County, Tex. USDA-SCS and Tex. Agr. Exp. Sta.

Vertessy, R. A., R. G. Benyon, S. K. O'Sullivan and P. R. Gribben. 1995. Relationships between stem diameter, sapwood area, leaf area and transpiration in a young mountain ash forest. Tree Physiol. 15:559- 567.

White, P. S. 1983. Corner's rules in eastern deciduous trees: allometry and its implications for the adaptive architecture of trees. Bull. Torrey Bot. Club. 110:203-212. 